\title{
Neonatal Listeria monocytogenes Infection is Refractory to Interferon
}

\author{
R. BORTOLUSSI, S. BURBRIDGE, P. DURNFORD, AND H. SCHELLEKENS \\ Departments of Pediatrics and Microbiology, Dalhousie University, Halifax, Canada /R.B., S.B., P.D.J and TNO \\ Primate Center, Ryswyk, The Netherlands [H.S.]
}

\begin{abstract}
Despite aggressive treatment, early onset neonatal Listeria monocytogenes infection continues to have high morbidity and mortality. We recently showed that pretreatment of newborn $L$. monocytogenes-infected rats with interferon (IFN)- $\alpha / \beta$ or recombinant rat IFN- $\gamma$ dramatically improves survival. However, in the present experiment, when newborn rats were treated with IFN- $\alpha$ / $\beta$ or recombinant rat IFN- $\gamma$ after intraperitoneal injection with Listeria there was no benefit. Because most deaths occurred at or before $3 \mathrm{~d}$ in this animal model, we reasoned that the effect of interferon may be evident if animals survived longer. To accomplish this and test this hypothesis, ampicillin $(20 \mathrm{mg} / \mathrm{kg} / \mathrm{d})$ was given $48 \mathrm{~h}$ after bacterial challenge. When ampicillin-treated Listeria-infected rats were randomized to receive PBS, IFN- $\alpha / \beta$, or recombinant rat IFN- $\gamma$, mortality rates were 79,76 , and $69 \%$, respectively ( $p>0.05$ versus PBS). Animals treated in a similar fashion after a lower bacterial inoculum ( $25 \%$ lethal dose) were killed $5 \mathrm{~d}$ after bacterial challenge. Bacterial concentrations in the spleen were higher for IFN-treated animals than controls. We conclude that no direct benefit of IFN is found if it is given after bacterial infection has been established. (Pediatr Res 29: 400-402, 1991)
\end{abstract}

\section{Abbreviations}

IFN, interferon

rRIFN- $\gamma$, recombinant rat interferon- $\gamma$

CFU, colony forming units

i.p., intraperitoneal(ly)

LAM, lipoarabinomannan

$\mathrm{LD}_{25}$ or $\mathrm{LD}_{90}, \mathbf{2 5 \%}$ and $\mathbf{9 0 \%}$ lethal dose, respectively

Listeria monocytogenes is the second or third most common cause of neonatal sepsis and meningitis (1). This short grampositive motile rod is thought to be pathogenic by virtue of its ability to survive intracellularly (2). Resistance to Listeria infection appears to be mediated by IFN $-\alpha / \beta$ and IFN- $\gamma$, which induce increased macrophage, lymphocyte, and natural killer cell activity in vivo and improve survival among pretreated Listeriainfected animals (3-12). Some investigators, however, have questioned the direct effect of IFN, suggesting instead that its role may be to enhance the activities of other lymphokines $(13,14)$. Despite this controversy, the effect of IFN pretreatment acting either directly or indirectly on Listeria-infected animals seems well established.

Received July 2, 1990; accepted December 4, 1990

Correspondence: Dr. R. Bortolussi, Infection and Immunology Research Laboratory, Jzaak Walton Killam Children's Hospital, Halifax, Nova Scotia, Canada B3J $3 G 9$.

Supported by the Medical Research Council of Canada, Grant No. MT 7610. R.B. is supported by MRC Development Grant No. DG 208.
In mature animals, L. monocytogenes infection induces production of IFN- $\alpha / \beta$ and IFN- $\gamma$. IFN- $\gamma$ is produced by immunologically active cells and can be induced by a variety of substances including $L$. monocytogenes $(3,5)$. The production of IFN- $\gamma$ is modulated or augmented by IL-1 (15) and lipopolysaccharide (5). IFN $-\alpha / \beta$ is produced by fibroblasts or leukocytes and is induced by $L$. monocytogenes infection as well as by other IFN inducers (7-9).

The human newborn is unusually susceptible to infection with L. monocytogenes (1). The reason for this is not entirely clear; however, immunologic elements important for host defense against Listeria are poorly developed in neonates $(16-18)$. Human neonatal cells produce little IFN when stimulated with mitogens and respond poorly to IL-2 stimulation (19). Despite this decreased activity and production of IFN, we recently showed that newborn rats have increased resistance to $L$. monocytogenes infection when pretreated with IFN or some IFN inducers (12). Because neonatal listeriosis has high mortality despite aggressive antibiotic treatment, we investigated the possibility that IFN might have an adjunctive therapeutic role. Here, we report the results of these studies using a newborn animal model. In contrast to our earlier studies in which IFN had a beneficial effect when given before infection, we found no improvement in animal survival or in bacterial load if animals were treated with IFN after infection was established.

\section{MATERIALS AND METHODS}

Reagents. Rat IFN- $\alpha / \beta$ was purchased from Lee Biophysics, San Diego, CA. rRIFN- $\gamma$ is the product of transfection with a plasmid carrying the chromosomal rat IFN- $\gamma$ gene as described elsewhere (20). IFN- $\alpha / \beta$ and $\mathrm{rRIFN}-\gamma$ were diluted in pyrogen free sterile PBS containing $0.1 \%$ albumin to a concentration of $10^{5} \mathrm{U} / \mathrm{mL}$ of stock solution. Lipopolysaccharide was not detectable in rRIFN- $\gamma(<1.0 \mathrm{ng} / \mathrm{mL})$ and was present in low concentration in IFN- $\alpha / \beta(\sim 10 \mathrm{ng} / \mathrm{mL})$. A strain of $L$. monocytogenes type $4 \mathrm{~b}$ (designated $15 \mathrm{U}$ previously) isolated originally from the blood of an infant with early onset neonatal sepsis was used in these studies $(21,22)$. Aliquots of a stock culture were stored in $20 \%$ glycerol and frozen at $-20^{\circ} \mathrm{C}$ until required for animal studies. A portion of the frozen aliquot was inoculated into brain heart infusion broth (BHI; Difco Laboratories, Detroit, MI) and incubated at $37^{\circ} \mathrm{C}$ overnight. The organism was sedimented $(3000 \times g$ for $10 \mathrm{~min})$ and washed once in PBS. The number of bacteria were estimated spectrophotometrically and confirmed for each experiment using the pour plate technique. Minimal inhibitory concentration of ampicillin against the organism as determined by serial dilution was $0.46 \mu \mathrm{g} / \mathrm{mL}$. The minimal bactericidal concentration was $3.20 \mu \mathrm{g} / \mathrm{mL}(22)$.

In vivo studies. Timed pregnant outbred Sprague Dawley rats (Canadian Hybrid Farms, Halls Harbour, Nova Scotia, Canada) were obtained at the 13th d of gestation, fed rat food ad libitum, and housed in a controlled environment $(12 \mathrm{~h}$ light/d) until parturition (usually on the 21 st or 22 nd d of gestation). 
For studies in which animals were pretreated with IFN, rat pups were injected i.p. with PBS or $10^{5} \mathrm{U} / \mathrm{kg}$ of IFN- $\alpha / \beta$ or rRIFN- $\gamma$ at 48 and $24 \mathrm{~h}$ before i.p. challenge with $L$. monocytogenes [1.0 $\pm 0.5 \times 10^{5} \mathrm{CFU}$ (mean $\pm \mathrm{SEM}$ ) per animal] which was given on $\mathrm{d} 3$ of life. This inoculation was equivalent to approximately $\mathrm{LD}_{25}$ in this schedule of injections. In these experiments, animals were killed by $\mathrm{CO}_{2}$ inhalation $3 \mathrm{~d}$ after bacterial challenge. The spleen was dissected free, weighed, and homogenized in PBS. Duplicate pour plates were prepared using serial dilutions in sterile water from the splenic homogenates and bacterial content expressed as $\mathrm{CFU} / 100 \mathrm{mg}$ of spleen. In all experiments, animals were returned to their mother when not being treated.

In studies in which animals were treated with IFN after bacterial challenge, 3 -d-old rats were injected i.p. with $1.0 \pm 0.5 \times$ $10^{6} \mathrm{CFU}$ for survival experiments or $1.8 \pm 0.1 \times 10^{5} \mathrm{CFU}$ for dissection experiments $\left(\mathrm{LD}_{90}\right.$ and $\mathrm{LD}_{25}$, respectively, in this experimental protocol). Forty-eight and $72 \mathrm{~h}$ later, they were injected s.c. with ampicillin $(20 \mathrm{mg} / \mathrm{kg} / \mathrm{d})$. In preliminary experiments, we established that this schedule and dose prevented death in approximately $40 \%$ of animals for an inoculum of 1.0 $\times 10^{6} \mathrm{CFU}$. Median survival was approximately $4 \mathrm{~d}$ for ampicillin-treated versus $3 \mathrm{~d}$ for untreated animals. Antibiotic-treated animals were randomly allocated to receive rRIFN- $\gamma$ or IFN- $\alpha$ / $\beta\left(10^{5} \mathrm{U} / \mathrm{kg}\right)$ i.p. at 48 and $72 \mathrm{~h}$ after bacterial challenge. Animals were killed $5 \mathrm{~d}$ after bacterial challenge and the spleens processed as described above.

Statistical analysis. Analysis of groups was done using a twosided paired $t$ test for comparison of concentration of bacteria in tissue. A $\chi^{2}$ test with Yates correction was used to compare survival of various groups (23).

\section{RESULTS}

In preliminary experiments, we found no improvement in survival or in bacterial content of spleen when newborn animals were injected with Listeria followed later by treatment with IFN$\alpha / \beta$. This was despite the fact that IFN $-\alpha / \beta$ was $100 \%$ protective when administered before infection at this dose (12). Inasmuch as in this animal model most deaths occurred at or before the 3 rd d of infection, we reasoned that no effect was evident because insufficient time had elapsed for IFN to act. We therefore modified the model by treating with antibiotics to prolong survival. A subcurative dose of ampicillin $(20 \mathrm{mg} / \mathrm{kg} / \mathrm{d})$ was deliberately chosen because we wished to assess the potential additive effects of IFN.

As shown in Figure 1, survival of Listeria-infected animals was better ( $p<0.05$ on $\mathrm{d} 4$ after challenge) if they were treated with ampicillin 48 and $72 \mathrm{~h}$ after bacterial challenge. However, addition of IFN- $\alpha / \beta$ or rRIFN- $\gamma$ to therapy did not improve survival any further for these animals. For all ampicillin-treated animals, including IFN- $\alpha / \beta$, rRIFN- $\gamma$, and placebo groups, medial survival was approximately $4 \mathrm{~d}$.

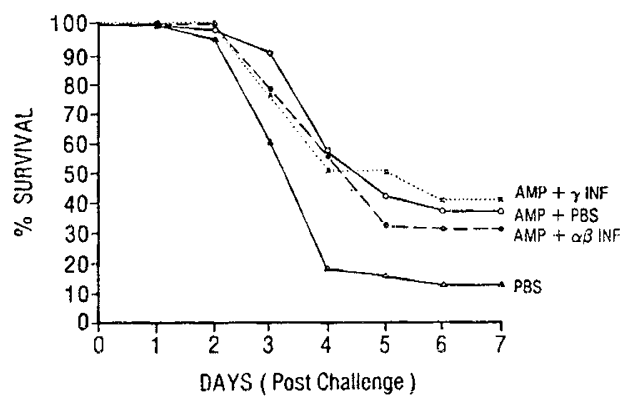

Fig. 1. Percent survival of 3-d-old rats after $L$. monocytogenes infection. Animals were injected with $1 \times 10^{6}$ CFU Listeria i.p. on $d 0$ followed by treatment on $\mathrm{d} 2$ and 3 with: PBS $(\boldsymbol{\Lambda}, 38$ animals), PBS and ampicillin $(\mathrm{O}, 85$ animals), IFN- $\gamma$ and ampicillin $(\times, 78$ animals), or IFN- $\alpha / \beta$ and ampicillin (๑, 74 animals).
Table 1. Effect of IFN given after bacterial challenge on Listeria-infected ampicillin-treated newborn rats

\begin{tabular}{lcc}
\hline \multicolumn{1}{c}{ Treatment* } & $\begin{array}{c}\text { No. of } \\
\text { animals }\end{array}$ & $\begin{array}{c}\text { Splenic bacterial } \\
\text { concentration } \dagger\end{array}$ \\
\hline PBS:PBS & 8 & $2.66 \pm 0.8$ \\
IFN- $\alpha / \beta:$ IFN- $\alpha / \beta$ & 8 & $3.53 \pm 1.1 \neq$ \\
rRIFN- $\gamma:$ rRIFN- $\gamma$ & 8 & $3.46 \pm 1.0 \neq$ \\
IFN- $\alpha / \beta:$ RIFN- $\gamma$ & 9 & $3.21 \pm 0.6 \neq$ \\
PBS:rRIFN- $\gamma$ & 8 & $3.08 \pm 1.1$ \\
\hline
\end{tabular}

${ }^{*}$ IFN $-\alpha / \beta$, rRIFN $-\gamma$, or PBS were injected i.p. at 48 and $72 \mathrm{~h}$ after i.p. injection of Listeria.

$\dagger$ Log CFU per $100 \mathrm{mg}$ splenic tissue $( \pm \mathrm{SD})$ for animals killed.

$\ddagger p<0.05$ vs PBS controls.

Table 2. Effect of IFN given before bacterial challenge on Listeria-infected newborn rats

\begin{tabular}{lcc}
\hline Treatment* & $\begin{array}{c}\text { No. of } \\
\text { animals }\end{array}$ & $\begin{array}{c}\text { Splenic bacterial } \\
\text { concentration } \dagger\end{array}$ \\
\hline PBS:PBS & 8 & $3.9 \pm 0.45$ \\
IFN- $\alpha / \beta:$ IFN- $\alpha / \beta$ & 7 & $3.5 \pm 0.69$ \\
rRIFN- $\gamma:$ rRIFN- $\gamma$ & 7 & $2.7 \pm 0.39 \ddagger$ \\
IFN- $\alpha / \beta$ :rRIFN- $\gamma$ & 7 & $2.6 \pm 0.56 \ddagger$ \\
PBS:rRIFN- $\gamma$ & 5 & $3.5 \pm 0.79$ \\
\hline
\end{tabular}

*IFN- $\alpha / \beta$, rRIFN- $\gamma$, or PBS were injected i.p. 48 and 24 h before i.p. injection of Listeria.

$\dagger$ Log CFU per $100 \mathrm{mg}$ splenic tissue $( \pm$ SD) for animals killed $72 \mathrm{~h}$ after last treatment.

$\neq p<0.05$ vs PBS controls.

We next considered the possibility that the inoculum of bacteria (approximately $\mathrm{LD}_{90}$ ) was too high to demonstrate any potential benefit of IFN. In a second experiment, bacterial challenge of animals was lowered to $1.8 \times 10^{5} \mathrm{CFU}$ (approximately $\mathrm{LD}_{25}$ ). As shown in Table 1 , bacterial content of spleen in Listeria-infected ampicillin-treated animals was not improved by treatment with two doses of $10^{5} \mathrm{U} / \mathrm{Kg}$ of IFN $-\alpha / \beta$ or rRIFN- $\gamma$ or a combination of these two IFN. In these experiments, bacterial load was lower ( $p<0.05$ two-sided $t$ test) for control animals that were not treated with IFN compared with groups of animals treated with IFN $-\alpha / \beta, \operatorname{rRIFN}-\gamma$, or IFN $-\alpha / \beta$ plus rRIFN- $\gamma$.

In contrast to this, newborn rats treated with IFN- $\alpha / \beta$, rRIFN$\gamma$, or IFN- $\alpha / \beta$ plus rRIFN- $\gamma$ before bacterial challenge had decreased $(p<0.05)$ bacterial concentration in the spleen (Table 2 ). In this experiment the bacterial inoculum was lower than in the first experiment and antibiotics were not given. The inoculum was approximately equivalent to a $\mathrm{LD}_{25}$ under these conditions. In addition, it is noteworthy that a single inoculation of rRIFN$\gamma$ produced lower bacterial loads only if it was preceded by IFN$\alpha / \beta$ and not by PBS.

\section{DISCUSSION}

$L$. monocytogenes is an intracellular pathogen that resides chiefly within the cells of the mononuclear phagocytic system. Although the underlying defect in newborn immunity to $L$. monocytogenes is not clearly understood, the failure of the macrophage to kill or inhibit the organism is a central factor. The macrophage has been shown to alter its metabolic, phagocytic, and bactericidal activity when stimulated by macrophage activating factor or recombinant IFN- $\gamma(24)$. Several investigators have studied the role of IFN- $\gamma$ in $L$. monocytogenes infection. In 1984, Kiderlen et al. (6) demonstrated that IFN- $\gamma$ pretreatment of mice led to their increased resistance to killing by L. monocytogenes. We and others have shown similar results using a newborn rat model of $L$. monocytogenes infection $(12,25)$.

These observations led us to speculate that IFN $-\gamma$ or IFN $-\alpha / \beta$ may have a potential therapeutic role in established infection. In 
the present experiments we examined this possibility. To our surprise, we showed no benefit of rRIFN- $\gamma$ or IFN- $\alpha / \beta$ when given by themselves or in combination with ampicillin to Listeria-infected newborn rats. This conclusion was drawn after studies on animal survival and bacterial load in spleens. In fact, use of IFN after bacterial challenge increased bacterial load in spleens. In contrast, the same dose of IFN given before bacterial challenge had an opposite effect. Bacterial load in the spleen was significantly decreased by pretreatment with two injections of rRIFN- $\gamma$. In addition, we have demonstrated here that a single injection with rRIFN- $\gamma$ was effective in limiting growth of Listeria in the spleen if animals were pretreated with IFN $-\alpha / \beta$ even though IFN $-\alpha / \beta$ by itself had no effect, suggesting that IFN $-\alpha / \beta$ may prepare the host for response to IFN- $\gamma$.

The overall conclusion from the experiments is that IFN modifies host response to $L$. monocytogenes infection differently if it is given after rather than before infection. The explanation for such an apparent paradox is at present unknown. Several explanations for these observations should be considered; products manufactured by the bacteria or products made by the host after infection may modify host responsiveness to cytokine. Alternatively, the sequence of cytokine appearance may be a critical factor.

That some organisms may produce exotoxins in vivo that render cells unresponsive to IFN has been shown for Mycobacterium leprae (26). Macrophages from animals infected with $M$. leprae are defective in their responsiveness to lymphokines including IFN- $\gamma$ even though these cells appear to be normal in other functions. The inhibiting effect of $M$. leprae is due to a major cell wall constituent, LAM, which specifically inhibits efferent functions of mouse macrophages. Preincubation with LAM resulting in uptake of LAM into cytoplasmic vacuoles of macrophages was necessary to show inhibition (26). No such product has been identified for $L$. monocytogenes. A second possibility is that a product secreted by the host may be induced during $L$. monocytogenes infection that renders the macrophages unresponsive. Such a macrophage deactivation protein, which blocks activation by IFN- $\gamma$ and reverses preexisting activation, has been identified from tumor cell lines (27). Finally, the possibility that the sequence of IFN appearance is crucial should be considered. Indeed, both an agonist and an antagonist effect of IFN- $\alpha / \beta$ has been demonstrated on activation of human macrophages depending on the time of introduction and concentration of this IFN in vitro (28). Others have described a synergistic interaction between IFN on transcription of IFN-stimulating genes only when the sequence of IFN introduction was controlled (29).

Although our observations should not be generalized to other animal species or infections, we believe that the therapeutic potential of IFN should be critically evaluated in similar models before clinical trials of it in such circumstances are undertaken.

Acknowledgment. The authors thank Deborah Briggs for her assistance in preparing this manuscript.

\section{REFERENCES}

1. Gellin BG, Broome CV 1989 Listeriosis. JAMA 261:1313-1320

2. Harrington-Fowler L, Henson PM, Wilder MS 1981 Fate of Listeria monocytogenes in resident and activated macrophages. Infect Immun 33:11-16

3. Buchmeier NA, Schreiber RD 1985 Requirement of endogenous interferon- gamma production for resolution of Listeria monocytogenes infection. Proc Natl Acad Sci USA 82:7404-7408

4. Havell EA, Spitalny GL, Patel PJ 1982 Enhanced production of murine interferon gamma by T-cells generated in response to bacterial infection. $J$ Exp Med 156:112-127

5. Havell E 1986 Augmented induction of interferons during Listeria monocytogenes infection. J Infect Dis 153:960-969

6. Kiderlen AF, Kaufmann SHE, Lohmann-Matthes M-L 1984 Protection of mice against the intracellular bacterium Listeria monocytogenes by recombinant immune interferon. Eur J Immunol 14:964-967

7. Nakane A, Minagawa T 1981 Alternative induction of IFN-alpha and IFNgamma by Listeria monocytogenes in human peripheral blood mononuclear leukocyte cultures. J Immunol 136:2139-2142

8. Nakane A, Minagawa $\mathrm{T} 1984$ The significance of alpha/beta interferons and gamma interferon produced by mice infected with Listeria monocytogenes. Cell Immunol 88:29-40

9. Nakane A, Minagawa T, Yasuda I 1985 Induction of alpha/beta interferon and gamma interferon in mice infected with Listeria monocytogenes during pregnancy. Infect Immun 50:877-880

10. McGregor DD, Chen-Woan M 1984 The cellular response to Listeria monocytogenes is mediated by a heterogeneous population of immunospecific $T$ cells. Clin Invest Med 7:243-252

11. Kaufmann SHE, Hug E, de Libero G 1986 Listeria monocytogenes-reactive Tlymphocyte clones with cytolytic activity against infected target cells. J Exp Med 164:363-368

12. Bortolussi R, Issekutz T, Burbridge S, Schellekens H 1989 Neonatal host defense mechanisms against Listeria monocytogenes infection: the role of lipopolysaccharides and interferons. Pediatr Res 25:311-315

13. Cheers C, Stanley ER 1988 Macrophage production during murine listeriosis: colony-stimulating factor 1 (CSF-1) and CSF-1-binding cells in genetically resistant and susceptible mice. Infect Immun 56:2972-2978

14. Havell EA 1987 Production of tumor necrosis factor during murine listeriosis. J Immunol 139:4225-4231

15. Dinarello CA, Savage N 1989 Interleukin 1 and its receptor. CRC Cr Rev Immunol 9:1-20

16. Kohl S, Loo LS, Drath DB, Cox P 1989 Interleukin-2 protects neonatal mice from lethal herpes simplex virus infection: a macrophage-mediated, $\gamma$ interferon-induced mechanism. J Infect Dis 159:239-247

17. Wilson CB, Westall J, Johnston L, Lewis DB, Dower SK, Alpert AR 1986 Decreased production of interferon-gamma by human neonatal cells. $\mathrm{J}$ Clin Invest 77:860 867

18. Wakasugi N, Virelizier J-L, Arenzana-Seisdedos F, Rothhut B, Huerta JM, Russo MF, Fiers W 1985 Defective IFN-gamma production in the human neonate: II role of increased sensitivity to suppressive effects of prostaglandin E. J Immunol 134:172-176

19. Johnston RB 1988 Monocytes and macrophages. N Engl J Med 318:747-752

20. Dijkema R, van der Meide PH, Pouwels PH, Coopers M, Dubbeld M, Schel lekens H 1985 Cloning and expression of the chromosomal immune interferon gene of the rat. EMBO J 4:761-767

21. Bortolussi R, Campbell N, Drause V 1984 Dynamics of Listeria monocytogenes type $4 \mathrm{~b}$ infection in pregnant and infant rats. Clin Invest Med 7:273-279

22. Hawkins AE, Bortolussi R, Issekutz AC 1984 In vitro and in vivo activity of various antibiotics against Listeria monocytogenes type $4 \mathrm{~b}$. Clin Invest Med $7: 335-341$

23. Dunn OJ 1977 Basic Statistics: A Primer for Biomedical Science, 2nd Ed. John Wiley and Sons Inc, New York, pp 81-102

24. Murray HW 1988 Interferon-gamma, the activated macrophage, and host defense against microbial challenge. Ann Intern Med 108:595-608

25. Chen Y, Nakane A, Minagawa T 1989 Recombinant murine gamma interferon induces enhanced resistance to Listeria monocytogenes infection in neonatal mice. Infect Immun 57:2345-2349

26. Sibley LD, Shirley WH, Brennan PJ, Drahenbuhl JL 1988 Mycobacterial lipoarabinomannan inhibits gamma interferon-mediated activation of macrophages. Infect Immun 56:1232-1236

27. Nathan CF, Tsunawake $S 1986$ Secretion of toxic oxygen products by macrophages: regulatory cytokines and their effects on the oxidase. In: Biochemistry of Macrophages, Ciba Foundation Symposia Ser No 118. Pitman, London, pp 211-230

28. Yoshida R, Murray HW, Nathan CF 1988 Agonist and antagonist effects of interferon $\alpha$ and $\beta$ on activation of human macrophages: two classes of interferon $\gamma$ receptors and blockade of high-affinity sites by interferon $\alpha$ or $\beta$. J Exp Med 167:1171-1185

29. Levy DE, Lew DJ, Decker T, Kessler DS, Darnell JE 1990 Synergistic interaction between interferon- $\alpha$ and interferon- $\gamma$ through induced synthesis of one subunit of transcription factor 1SGF-3. EMBO J 9:1105-1111 